\title{
A thermoeconomic indicator for the sustainable development with social considerations
}

\section{A thermoeconomy for sustainable society}

\author{
Umberto Lucia $^{1} \mathbb{D} \cdot$ Debora Fino $^{1} \cdot$ Giulia Grisolia $^{1}$
}

Received: 25 July 2020 / Accepted: 11 May 2021 / Published online: 20 May 2021

(C) The Author(s) 2021

\begin{abstract}
The United Nations action plan Agenda 21 has represented a milestone toward Sustainable Development. On its 40th Chapter, it is introduced the requirement to dispose of an accurate and continuous collection of information, essential for decision-making. Besides bridging the data gap and improving the information availability, it is highlighted the need to dispose of sustainable development indicators, in order to assess and monitor the performances of countries toward sustainability. In this paper, we develop an improvement of a new indicator, recently introduced linking environmental anthropic footprint and social and industrial targets. Here, we suggest a link with the Income Index, in order to consider also a condition of people well-being. Our results consists in an improvement of the present approaches to sustainability; indeed, we link the socio-economic considerations, quantified by the Income Index and the Human Development Index, to the engineering approach to optimization, introducing the thermodynamic quantity entropy generation, related to irreversibility. In this way, two different new indicators are introduced, the Thermodynamic Income Index and the Thermodynamic Human Development Index, which quantitatively express a new viewpoint, which goes beyond the dichotomy between socio-economic considerations on one hand and engineering and scientific approach to sustainability on the other one. So, the result leads to a unified tool useful for the designing of new policies and interventions for a sustainable development for the next generations.
\end{abstract}

Keywords Entropy $\cdot$ Economic indicator $\cdot$ Social physics $\cdot$ Sustainability $\cdot$ Bioeconomy

PACS 89.65.Gh

Umberto Lucia

umberto.lucia@polito.it

1 Politecnico di Torino, Torino, Italy 


\section{Introduction}

The use of a continuous increasing amount of energy has been fundamental for the human development. Indeed, a key factor for socio-economic development of societies can be identified in the capability to manage flows of energy and materials (Cleveland et al. 1984). During the evolution of human history, specially from the industrial era up to now, our society has begun to need always more power and to deeply depend on fossil fuels.

However, nowadays, there are main concerns linked to the use of fossil fuels, not last those related to environment and sustainability. The increase in greenhouse gasses (GHGs) and pollutant emissions on the one hand, and the depletion of fossil fuel resources on the other one, are driving the scientific research to find alternative sources of energy and technologic solutions to burn less fuel and to reduce pollutant emissions.

So, in the last decades, increasing and optimizing energy efficiency has become a highpriority for all engineering areas, specially in relation to sustainability, sustainable development and to the rational use of resources.

\subsection{The key challenge of sustainability}

Sustainability and sustainable development represent a key challenge of our Century for all the disciplines. Since 1983, the World Commission on Environment and Development (WCED) started to work on problems related to environment and development, trying to advance tools to orient the international community to solve them. The goal of the Brundtland Commission was to try to optimize the process of development considering three different dimensions of it: the economical, the environmental and the social one (Spangenberg et al. 2002).

Therefore, it has become common to describe Sustainable Development through the three interlinked pillars of sustainability (Purvis et al. 2019):

- Economic;

- Social;

- Environmental.

This concept is often presented graphically trough a Venn diagram, with three intersecting circles (the three main domains of sustainability) (Mensah 2019), where only the overlap area of the three domains implies sustainable development. The first literature work in which is presented this conceptualization is by Barbier in 1989 Barbier (1987). Barbier also calls it systems approach (Barbier and Burgess 2017), where emerges the need not to maximize the single goals of each subsystem (economic, social and environmental) but to find a continuous balance of trade-offs among this different goals, without ignoring the consequences on the other subsystems. The most important aspect to take into account is that an action, which is in accordance with sustainable development, must consider at the same time the three main domains of sustainability.

\subsection{Brief history of sustainable development and the need to measure it}

Sustainable development started to be promoted in the early Seventies in order to reach suitable environment setting (Asr et al. 2019) in the course of the development both of societies and of technical progress. In this context, the work "The limits to Growth" 
Meadows et al. (1972), commissioned by the Club of Rome, can be considered a precursor on this topic, where the authors have developed a model to realize a simulation of the interaction human-Earth in which are taken into account five main variables: consumption of non-renewable resources, industrialization, food production, pollution and population. Being the natural resources upper limited (finite quantities) and assuming an exponential growth of the main variables (according to the previous historical data) (Basiago 1999), the authors concluded that there exists an upper limit of time, persevering this kind of behavior (Norman 2009).

The term Sustainable development first appeared officially in 1980, in the World Conservation Strategy Report (IUCN 1980), where emerged the need for a global approach to the administration of resources on which anthropic activities and development rely on. Indeed, the focus of this report was on two main issues:

- Conservation, referred to the necessity for conservation of our living ecosystem, limiting ecosystems degradation and all the problems related with negative human beings taking into account the needs of the future generations;

- Interrelation of actions at a global level which highlights the responsibility of local actions, which all have a rebound at a global scale.

This document was addressed to government policy makers, to the people who works in strictly contact with natural resources and development practitioners (IUCN 1980) with the aim to reach sustainable development stimulating an approach based on conservation and awareness of human actions.

So, fifty years ago, clearly emerged the request of a more sustainable way of management of Earth resources use, since it was noticed the failure of integrating conservation with development.

In 1986, the International Union for Conservation of Nature (IUCN), identified five requirements to realize sustainable development, which can be summarized as Jacobs et al. (1987):

1. Integrating conservation and development;

2. Meeting human needs;

3. Reaching equity and social justice;

4. Providing social self-determination and cultural diversity;

5. Maintaining ecosystem integrity.

The most often cited definition of Sustainable development (Schaefer and Crane 2005) as the development which responds to the present requirements without compromising the potentiality of the next generations (WCED 1987). This report has put the spotlight on sustainable development both in the scientific community (Castro 2004) and in the international policy framework (Johnston et al. 2007). The Brundtland Report is divided into three main parts: common concerns, common challenges and common endeavors; in all of them emerges the requirement of link economic growth to social equity and environmental concerns.

The WCED put the spotlight on sustainable development (Castro 2004) and, in the wake of the Brundtland Report's contents, in 1992, the largest world's leaders meeting ever noticed (Basiago 1999) was held in Brazil: it is known as "Rio Earth Summit." The aim of this event was to create an international partnership in order to implement strategies for 
sustainable development for the entire global population (Cicin-Sain 1996). It followed the creation of a Commission to Sustainable Development to purse the Agenda 21 progresses. Some of the mechanisms introduced to implement the targets of Agenda 21 were the:

- Program for the Further Implementation of Agenda 21 in 1997;

- United Nations Millennium Development Goals (MDGs) or International Development Goals in 2000.

With the Agenda 21 emerged the need to dispose of tools to measure sustainable development: indicators were identified as the suitable tool to the assessment and continuous improvement of the development of nations (Strezov et al. 2016).

In 2002 was held the Johannesburg World Conference on Sustainable Development, identified as the first international gathering in which factors concerning economy, society and environment were purposed to underpin sustainable development. Nine years later, the concept of triple helix was introduced in the UN Environment Programme (UNEP). This idea encloses the three factors as being intertwined in a helical shape (Haines et al. 2012), highlighting the complexity of the topic.

Last, in 2015, the Sustainable Development Goals (SDGs) were introduced by the United Nations General Assembly with the objective to fulfil them by 2030 . They are presented within the Agenda 2030 and, to each one of them corresponds a list of goals to achieve (169 in overall), which are measurable by means of at least one indicator (232 overall approved indicators). The principal areas on which is focused the Agenda 2030 are United Nations (2015):

- People the first SDG is "No poverty," to obtain in all its forms and for all people;

- Planet which means protecting and preventing irreversible damages to the ecosystem, acting against climate changes;

- Peace in order to have peaceful societies in all corners of the world;

- Prosperity which means progress and well-being from an economic and social point of view both for humans and nature;

- Partnership to fulfil all the goals of the agenda mutual aid and agreements are needed.

\subsection{Indicators of sustainability}

In literature there are several international studies and reviews on indicators of sustainability, as deep analyzed in Refs. Munda (2005); Wilson et al. (2007); Böhringer and Jochem (2007); Moran et al. (2008); Nourry (2008); Steinberger (2008); Siche et al. (2008); Steuer (2013); Fiksel et al. (2012); Evans et al. (2015); Liu et al. (2017); Borgnäs (2017); Raucci and Tarquinio (2020); Kravchenko et al. (2020). Furthermore, a large number of indicators for sustainable development have been proposed for specific sectors and aspects, such as concerns energy use, energy efficiency and exergy analysis (Hacatoglu et al. 2015; Dincer and Acar 2015; Abu-Rayash and Dincer 2021; Sciubba 2013; Romero and Linares 2014; Sciubba 2019), circular economy (Primc et al. 2020; Santagata et al. 2020; Rossi et al. 2020; Pascale et al. 2021), industrial supply chains (Neri et al. 2021) but also sustainability of biofuels production (Mayer et al. 2020; Lucia and Grisolia 2018), biomass-based carbon chemicals (Horváth et al. 2017), agriculture (de Olde et al. 2017; Janker and Mann 2020), emerging technologies (Açkkalp and Ahmadi 2018; Meramo-Hurtado and González-Delgado 2020), etc.. Moreover, the 
need to assess sustainability must be coupled with the requirement of decent standards of quality of life (Eras et al. 2013) and human well-being.

Therefore, in order to support decision-making activities toward sustainability, researchers and International Organizations have been working in propose new indicators. In 1989, Cobb introduced the Index of Sustainable Economic Welfare (ISEW) as an alternative to the Gross Domestic Product (GDP) (Cobb 1989). Then, Cobb himself, extended his indicator (Cobb and Cobb 1994; Cobb et al. 1999), developing the Genuine Progress Indicator (GPI), which contains aspects of all three domains of sustainable development.

Another indicator of sustainability, introduced in the 1990s, was the Ecological Footprint (EF), which considers the surface of productive land required to support a given population at its actual level of consumption (Rees 1992; Moldan et al. 2012). In order to measure the annual total capital stock of a country, including also the wealth accounting, the Genuine Savings Indicator (GSI) has been presented (Hamilton and Naikal 2014; Hamilton and Hepburn 2014).

The Environmental Sustainability Index (ESI) is a composite index to assess sustainability, by using environmental and socio-economic indicators (Esty et al. 2005). This index encloses 21 different indicators, which are combined with two to eight variables (76 overall variables) (Wilson et al. 2007). Then, this composite index has been modified, by adding some indicators regarding human health and environmental issues, designing the Environmental Performance Index (EPI). The latter identifies economic and social driving forces, and environmental pressures, assesses the impacts on human health, and on the environment (Hsu et al. 2013).

The Sustainable Society Index (SSI) is a composite index which encompasses indicators of all three main domains of sustainability which has been introduced to measure the level of sustainability of a country including the most important aspects of sustainability and quality of life of a national society (de Kerk and Manuel 2008).

Another index built as an alternative to the GDP is the Happy Planet Index (HPI), which measures the trade-off between ecological footprint data and life quality (Tausch 2011), with a subjective measure of well-being (Campus and Porcu 2010).

One of the landmarks among the indicators of sustainable development is the Human Development Index (HDI) which was proposed in the early 1990s by the United Nations Development Programme (United Nations Development Programme 1990; UNDP 1990; Sagar and Najam 1998). It is a multidimensional index which measures the development of a country from a socio-economic stand-point, focusing in human well-being by considering key parameters of social development (Sagar and Najam 1998; Hickel 2020). During the last thirty years, this indicator has been updated and improved (Liu et al. 2017; Hickel 2020; UNDP 2010, 2015).

In Table 1, the main indicators presented in literature, are summarized in relation to their chronological introduction and, in Table 2, are highlighted the main dimensions of sustainability encompassed by each one of them.

Despite the big efforts made in the last decades in defining new indicators of sustainability and sustainable development, there are still open problems with their definition and acceptance. In order to overcome this issues is fundamental to dispose of an interdisciplinary approach based on policy-making and sciences, concerning all the relevant aspects of sustainability (Strezov et al. 2016). 


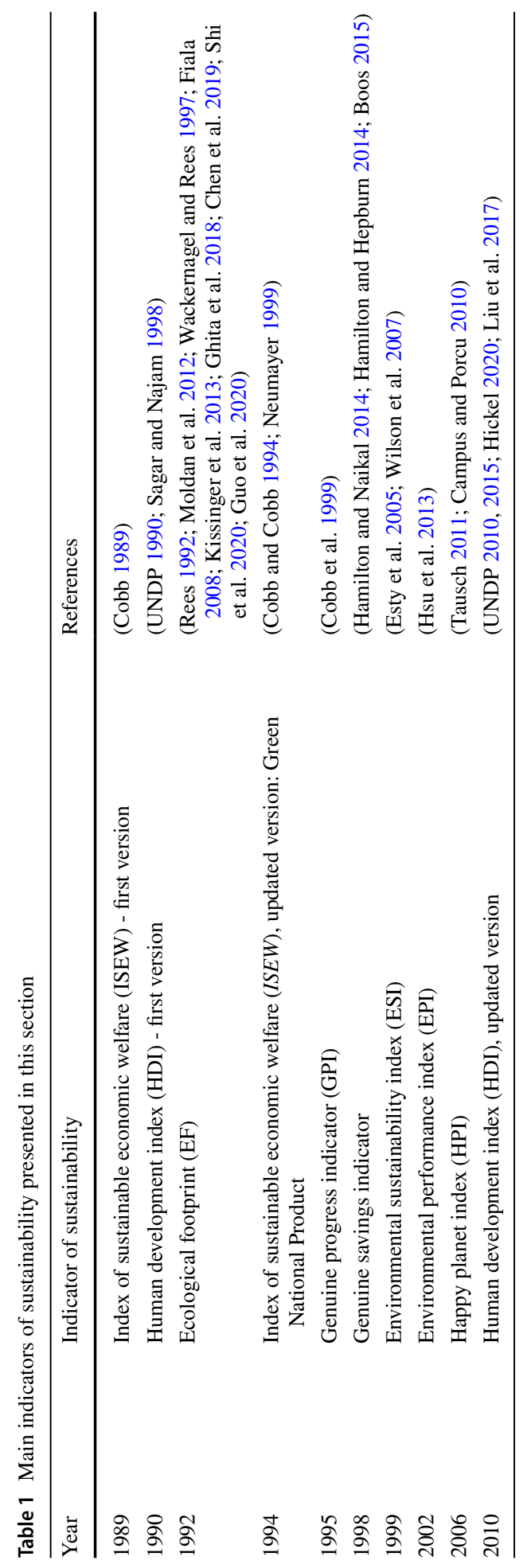


Table 2 Indicators of sustainability presented in this Section with their contribution to economic, social and environmental dimensions

\begin{tabular}{llll}
\hline Indicator & Economic & Environmental & Social \\
\hline EF & $\times$ & $\checkmark$ & $\times$ \\
EPI & $\times$ & $\checkmark$ & $\checkmark$ \\
ESI & $\times$ & $\checkmark$ & $\checkmark$ \\
GPI & $\checkmark$ & $\checkmark$ & $\checkmark$ \\
GSI & $\checkmark$ & $\checkmark$ & $\checkmark$ \\
HDI & $\checkmark$ & $\times$ & $\checkmark$ \\
HPI & $\times$ & $\checkmark$ & $\checkmark$ \\
ISEW & $\checkmark$ & $\checkmark$ & $\checkmark$ \\
SSI & $\checkmark$ & $\checkmark$ & $\checkmark$ \\
\hline
\end{tabular}

\subsection{The focus of this paper}

In this paper, a thermodynamic approach recently developed (Grisolia et al. 2020; Lucia et al. 2020; Lucia and Grisolia 2018) is improved with particular regards to its link with Income Index. The aim of this paper is to develop a new viewpoint based on the fundamentals of sustainable development, considered both from a socio-economic and an engineering viewpoint. To do so, in Section Theory we will develop an analytical approach to improve the present socio-economic indicators, by introducing the entropy generation in order to take into account the engineering quantity used in optimization approach to designing. In Section Discussion, we will highlight how the new indicators obtained can be part of the present context on sustainability, improving the present approaches in relation of going beyond the present dichotomy between socio-economic and engineering and scientific approaches to sustainability.

\section{Theory and methodology}

Usually, indicators and indexes are the main tools used to assess performances by policy-makers, statisticians, economists. Following the definition given by the Organization for Economic Co-operation and Development (OECD) (OECD 2008), an indicator is an instrument used to measure, quantitatively or qualitatively, based on the observation of reality, focused on the aspects that can disclose and enable comparisons. Indicators are used by policy-makers for analyzing and comparing trends of the different Countries, for driving the attention to some specific topics, for determining policy priorities, for surveying performances.

In this section, the link between a new indicator (Lucia and Grisolia 2019) to the wealth and purchasing power is developed. To do so, we first consider some indicator, just accepted and used in literature and by the International Organizations, then we introduce the thermodynamic analysis to irreversibility, as usually developed in engineering optimization, last we introduce new indicators in order to improve the present treatment of sustainability in relation to well-being and ecological impact.

So, the first step in our approach is to consider the following indicators:

- The exergy intensity (Grisolia et al. 2020): 


$$
\mathrm{ExI}=\frac{\mathrm{Ex}_{\mathrm{in}}}{\mathrm{GDP}}
$$

where $\mathrm{Ex}_{\mathrm{in}}$ is the input exergy. This indicator is analogous to the ECO2 presented in IAEA (2005) but, it considers exergy instead of energy, which means introducing the irreversibility and the energy quality;

- The labor productivity, LP, defined as OECD (2019); Blain (1996); Zhang and Dornfeld (2007):

$$
\mathrm{LP}=\frac{\mathrm{GDP}}{n_{\mathrm{wh}}},
$$

where $n_{\mathrm{wh}}=n_{w} \cdot n_{h}$ is the total number of worked hours needed to obtain the GDP, where $n_{h}$ is number of worked hours, and $n_{w}$ is the number of workers;

- The Second Law Inefficiency $\eta_{\lambda}$, defined as Lucia and Grisolia (2019):

$$
\eta_{\lambda}=\frac{W_{\lambda}}{\mathrm{Ex}_{\mathrm{in}}}
$$

where $W_{\lambda}$ is the work lost due to irreversibility and friction (Bejan and Lorente 2004). In accordance with the Gouy-Stodola theorem (Bejan 2006), the work lost due to irreversibility $W_{\lambda}$, can be evaluated by multiplying the environmental temperature $T_{0}$ with the entropy variation due to irreversibility, $S_{\mathrm{g}}$. So, we introduce an quantitative expression of the new indicator by considering the well-being and purchasing power:

$$
I=\eta_{\lambda} \cdot \operatorname{ExI} \cdot \mathrm{LP}=\frac{W_{\lambda}}{n_{w} \cdot n_{h}}=\frac{T_{0} S_{\mathrm{g}}}{n_{w} \cdot n_{h}}=\frac{T_{0} S_{\mathrm{g}}}{n_{\mathrm{wh}}},
$$

where $n_{\mathrm{wh}}$ is strictly related both to the result of the work and to the Gross National Income per capita.

So, we modify our indicator of Eq.(4) by considering the useful work and the $\mathrm{GNI}_{\mathrm{pc}}$, as follows (Lucia and Grisolia 2021):

$$
I_{\mathrm{T}}=\frac{T_{0} \dot{S}_{\mathrm{g}}}{\dot{W} \cdot \mathrm{GNI}_{\mathrm{pc}}},
$$

where $\dot{W}$ is the useful power obtained by the process considered, and $S_{g} / W=\dot{S}_{\mathrm{g}} / \dot{W}$. Now, it is possible to relate the indicator with the normalized Income Index (II), used in the United Nations Development Program, which is defined as follows (Pinar et al. 2017; Kahneman and Deaton 2014):

$$
\mathrm{II}=\frac{\ln \left(\mathrm{GNI}_{\mathrm{pc}} / 100\right)}{\ln (75000 / 100)},
$$

where $\mathrm{GNI}_{\mathrm{pc}}$ is the gross national income per capita, where the minimum and the maximum value are $100.00 \$$ and $75000.00 \$$, respectively. So, the indicator useful to link the environmental and the economic purchase power results:

$$
I_{\mathrm{T}}=\frac{T_{0} \dot{S}_{\mathrm{g}}}{\dot{W} \cdot \mathrm{GNI}_{\mathrm{pc}}}=0.01 \cdot \frac{T_{0} \dot{m}_{\mathrm{CO} 2} S_{\mathrm{g}}}{\dot{W}} \cdot 750^{-11},
$$


where $\dot{m}_{\mathrm{CO}} 2$ is the carbon dioxide flux due to anthropic activities and $s$ is its specific entropy. Consequently, this result introduces the carbon dioxide fluxes, linked to environmental impact, the entropy generation, linked to the technological level, into the economic analysis based on the Income Index. This result improves the Income Index indicator by considering also the technological and ecological level of a country. Consequently, it appears interesting also in relation to the United Nations (UN) approach to evaluate the well-being of Countries; indeed, UN has introduced the Human Development Index, HDI, in order to consider the developing level of any country, in relation to education, health and salary conditions. The index HDI is a composite indicator,focused on three keys of the countries development:

- The possibility to lead a long and healthy life, quantified by the life expectancy at birth;

- The possibility to achieve a good level of knowledge, quantified by the amount and the expected years of schooling;

- The possibility to achieve a decent standard of living, quantified by the gross national income per capita, just related to Income Index (II), and also to the Thermodynamic Income Index $\left(I_{\mathrm{T}}\right)$.

The HDI is analytically defined as United Nations Development Program (2020); UNDP (2015):

$$
\mathrm{HDI}=(\mathrm{LI} \cdot \mathrm{EI} \cdot \mathrm{II})^{1 / 3},
$$

where LI $=(\mathrm{LE}-20) / 65$ is the Life Expectancy Index (Türe and Türe 2021), with LE Life expectancy at birth (World Bank Group 2021), EI = (MYSI + EYSI) $/ 2$ is the Education Index, with MYSI the Mean Years of Schooling Index and EYSI = ESI/18 Expected Years of Schooling Index (Stanton 2007). But, HDI doesn't take into account the technological and ecological level. So, we can introduce our new indicator, $I_{\mathrm{T}}$, into the HDI definition, by using the relation (7), in order to take into account also the ecological impact of the human activities, considering the environmental conditions a fundamental key of human well-being; so, we can redefine the HDI as Thermodynamic Human Development Index THDI as follows (Lucia and Grisolia 2021):

$$
\mathrm{THDI}=\left(\frac{\mathrm{LI} \cdot \mathrm{EI}}{I_{\mathrm{T}}}\right)^{1 / 3}
$$

\section{Results and discussion}

In Chapter 40 of Agenda 21 is introduced the requirement to have the availability of information and data about the conditions of each single State, and emerges the need to develop indicators of sustainable development to provide a basis for decision-makers, in order to allow them to support sustainability by their policy (United Nations General Assembly 1992).

So, in order to evaluate the advance on the implementation of Agenda 21, a set of indicators of sustainable development was developed by the Commission on Sustainable 
Development in 1995, adding to the common three dimensions (social, economic and environmental) the institutional one.

In the first work of the CSD with the UN Department of Economic and Social Affairs (UNDESA) (UNDESA, CSD 1996), 134 indicators of sustainable development were presented, with their relative methodologies to adopt in using them. To classify them, the CSD initially used the "Pressure - State - Response" framework (Levrel et al. 2009), introduced by OECD (OECD 1993) for Environmental Indicators, but this approach was more suitable for the environment but not fully complete to include also the social and economic aspects. Thus, it was modified substituting "Pressure" with "Driving force." After the national testing of the proposed indicators, the "Driving force - State - Response" was modified into "Policy issues" or, better, in main themes and sub-themes (IAEA 2005).

A core set of Energy Indicators for Sustainable Development (EISD) has been carried out by different institutions: the International Atomic Energy Agency (IAEA), the United Nations Department of Economic and Social Affairs (UNDESA), the International Energy Agency (IEA), Eurostat, and the European Environment Agency (EEA). Here, we summarize the properties of the fundamental indicators involved the usual analyses of the sustainability energy uses:

- Social, which is related to accessibility, affordability, disparities, and safety;

- Economic, which is related to the energy use pro capita, the energy per GDP, the productivity, the efficiency, the economic sector use of energy, the import/export of energy resources, and strategic market of reference;

- Environmental, which is related to atmosphere, water, and lands, with particular regards to climate change, air and water and soil quality, deforestation prevention and the energy generation and management.

Energy need, use and consumption have a central role in our daily life, and society. So, the management of its fluxes, and all its production and consumption chains, are fundamental to ensure a correct approach to sustainability and sustainable development. This aspect can not be neglected considering an effective indicator of sustainability and, using a thermodynamic approach, can be a powerful tool to improve existing indicators.

Our results can be considered an improvement of the approach to sustainability as here summarized, because we can link the socio-economic considerations to the engineering approach to optimization, by the introduction of the thermodynamic quantity entropy generation. So, the new indicators $I_{\mathrm{T}}$ and THDI represent a new viewpoint, which goes beyond the dichotomy between socio-economic considerations, and engineering and scientific approach to sustainability, obtaining a unified tool to design new policies and activities, for the next future.

\section{Conclusions}

The result here obtained consists in an improvement of an indicator recently introduced in Lucia and Grisolia (2019, 2017); Lucia (2016).

Our previous indicator allows us to analyze the technological processes by using a holistic approach based on thermodynamics: it considers all the interactions internal to the process (Lucia and Grisolia 2019; Lucia 2016). Moreover, it takes also into account the related consumption rate of the available resources (Sciubba and Zullo 2011). 


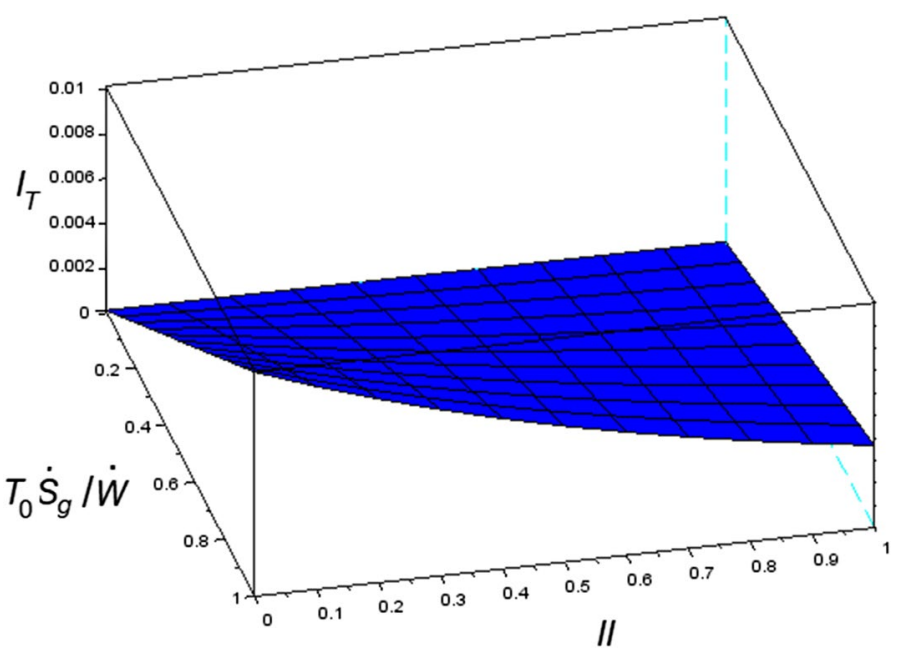

Fig. 1 Shape of the indicator. The indicator assumes the lower values if the anthropic consequences are low and if the well-being and the purchasing power are high

Up now, the community and the environment have been considered separately, even if it is clear that they are interacting systems. The indicators here proposed introduce the entropy approach into economic analysis of sustainability, and the improvement here proposed allows us to consider also the need of people in relation to well-being and purchasing power. Indeed, our indicator assumes the lower values if the anthropic consequences are low and if the well-being and purchasing power are high, as represented in Fig. 1. In this Figure, it is possible to highlight that a process is considered sustainable if the indicators $I_{\mathrm{T}}$ and $T_{0} \dot{S}_{\mathrm{g}} / \dot{W}$ are as low as possible and the indicator II is as greater as possible.

Consequently, a process is considered sustainable if the indicator $I_{\mathrm{T}}$ is as low as possible and the indicator THDI is as greater as possible.

Author Contributions UL and GG involved in conceptualization; UL involved in methodology; GG developed software; UL, DF and GG validated the manuscript; UL and GG involved in formal analysis; UL, DF and GG investigated the study; UL and DF involved in resources; GG participated in data curation; UL, DF and GG involved in writing - original draft preparation; UL and GG involved in writing-review and editing; GG visualized the study; UL and DF supervised the study; UL and DF involved in project administration; UL and DF participated in funding acquisition; All authors have read and agreed to the published version of the manuscript.

Funding Open access funding provided by Politecnico di Torino within the CRUI-CARE Agreement.

Open Access This article is licensed under a Creative Commons Attribution 4.0 International License, which permits use, sharing, adaptation, distribution and reproduction in any medium or format, as long as you give appropriate credit to the original author(s) and the source, provide a link to the Creative Commons licence, and indicate if changes were made. The images or other third party material in this article are included in the article's Creative Commons licence, unless indicated otherwise in a credit line to the material. If material is not included in the article's Creative Commons licence and your intended use is not permitted by statutory regulation or exceeds the permitted use, you will need to obtain permission directly from the copyright holder. To view a copy of this licence, visit http://creativecommons.org/licenses/by/4.0/. 


\section{References}

Abu-Rayash, A., \& Dincer, I. (2021). Development of integrated sustainability performance indicators for better management of smart cities. Sustainable Cities and Society, 67, 102704. https://doi.org/10. 1016/j.scs.2020.102704.

Açkkalp, E., \& Ahmadi, M. (2018). Exergetic ecological index as a new exergetic indicator and an application for the heat engines. Thermal Science and Engineering Progress, 8, 204. https://doi.org/10.1016/j. tsep.2018.09.001.

Asr, E. T., Kakaie, R., Ataei, M., \& Mohammadi, M. T. (2019). A review of studies on sustainable development in mining life cycle. Journal of Cleaner Production, 229, 213.

Barbier, E. (1987). The concept of sustainable economic development. Environmental Conservation, 14, 101.

Barbier, E., \& Burgess, G. (2017). The sustainable development goals and the systems approach to sustainability. Economics - The Open Access, Open-Assessment E-Journal, 11, 1.

Basiago, A. (1999). Economic, social, and environmental sustainability in development theory and urban planning practice. The Environmentalist, 19, 145.

Bejan, A. (2006). Advanced engineering thermodynamics. New York: Wiley.

Bejan, A., \& Lorente, S. (2004). The constructal law and the thermodynamics of flow systems with configuration. International Journal of Heat and Mass Transfer, 47, 3203.

Blain, R. R. (1996). Defining exchange rate parity in terms of GDP per hour of work. Applied Behavioral Science Review, 4, 55.

Böhringer, C., \& Jochem, P. (2007). Contrasting and comparing sustainable development indicator metrics. Ecological economics, 63, 1. https://doi.org/10.1016/j.ecolecon.2007.03.008.

Boos, A. (2015). Genuine savings as an indicator for weak sustainability: Critical survey and possible ways forward in practical measuring. Sustainability, 7, 4146.

Borgnäs, K. (2017). Indicators as "circular argumentation constructs"? An input-output analysis of the variable structure of five environmental sustainability country rankings. Environment Development and Sustainability, 19, 769. https://doi.org/10.1007/s10668-016-9764-0.

Borgnäs, K. (2017). Indicators as circular argumentation constructs? An input-output analysis of the variable structure of five environmental sustainability country rankings. Environment Development and Sustainability, 19, 769. https://doi.org/10.1007/s10668-016-9764-0.

Campus, A., \& Porcu, M. (2010). Reconsidering the well-being: The happy planet index and the issue of missing data. Cagliari: Centro Ricerche Economiche Nord Sud.

Castro, C. (2004). Sustainable development: Mainstream and critical perspectives. Organization \& Environment, 17, 195.

Chen, G., Li, Q., Peng, F., Karamian, H., \& Tang, B. (2019). Henan ecological security evaluation using improved 3D ecological footprint model based on emergy and net primary productivity. Sustainability, 11, 1353.

Cicin-Sain, B. (1996). Earth Summit implementation: Progress since Rio. Marine Policy, 20, 123.

Cobb, C., Goodmann, G., \& Wackernagel, M. (1999). Why bigger isn't better?: The genuine progress indicator?: 1999 update. San Francisco: Redefining Progress.

Cobb, C. (1989). The index for sustainable economic welfare. Boston: Beacon Press.

Cobb, C., \& Cobb, J. (1994). The green national product: A proposed index of sustainable economic welfare. Lanham: University Press of America.

de Kerk, G. V., \& Manuel, A. (2008). A comprehensive index for a sustainable society: The SSI - the sustainable society index. Ecological Economics, 66, 228. https://doi.org/10.1016/j.ecolecon.2008.01.029.

de Olde, E., Moller, H., Marchand, F., McDowell, R., MacLeod, C., Sautier, M., et al. (2017). When experts disagree: The need to rethink indicator selection for assessing sustainability of agriculture. Environment Development and Sustainability, 19, 1327. https://doi.org/10.1007/s10668-016-9803-x.

Dincer, I., \& Acar, C. (2015). A review on clean energy solutions for better sustainability. International Journal of Energy Research, 39, 585. https://doi.org/10.1002/er.3329.

Eras, J. C., Varela, D. C., Pérez, G. H., Gutiérrez, A. S., Lorenzo, D. G., Vandecasteele, C., \& Hens, L. (2013). Comparative study of the urban quality of life in Cuban first-level cities from an objective dimension. Environment, Development and Sustainability, 16, 195. https://doi.org/10.1007/ s10668-013-9470-0.

Evans, A., Strezov, V., \& Evans, T. (2015). Measuring tools for quantifying sustainable development. European Journal of Sustainable Development, 4, 291. https://doi.org/10.14207/ejsd.2015.v4n2p291.

Fiala, N. (2008). Measuring sustainability: Why the ecological footprint is bad economics and bad environmental science. Ecological Economics, 67, 519. 
Ghita, S. I., Saseanu, A., Gogonea, R., \& Huidumac-Petrescu, C. (2018). Perspectives of ecological footprint in European context under the impact of information society and sustainable development. Sustainability, 10, 3224.

Grisolia, G., Fino, D., \& Lucia, U. (2020). Thermodynamic optimisation of the biofuel production based on mutualism. Energy Reports, 6, 1561.

Guo, J., Ren, J., Huang, X., He, G., Shi, Y., \& Zhou, H. (2020). The dynamic evolution of the ecological footprint and ecological capacity of Qinghai province. Sustainability, 12, 3065.

Hacatoglu, K., Dincer, I., \& Rosen, M. (2015). A new model to assess the environmental impact and sustainability of energy systems. Journal of Cleaner Production, 103, 211. https://doi.org/10.1016/j.jclep ro.2014.06.050.

Haines, A., Alleyne, G., Kickbusch, I., \& Dora, C. (2012). From the Earth Summit to Rio+20: integration of health and sustainable development. The Lancet, 379, 2189.

Hamilton, K., \& Hepburn, C. (2014). Wealth. Oxford Review of Economic Policy, 30, 1.

Hickel, J. (2020). The sustainable development index: Measuring the ecological efficiency of human development in the anthropocene. Ecological Economics, 167, 106331.

Horváth, I., Cséfalvay, E., Mika, L., \& Debreczeni, M. (2017). Sustainability metrics for biomass-based carbon chemicals. ACS Sustainable Chemistry and Engineering, 5, 2734. https://doi.org/10.1021/acssu schemeng.6b03074.

Hsu, A., Lloyd, A., \& Emerson, J. W. (2013). What progress have we made since Rio? Results from the 2012 Environmental Performance Index (EPI) and Pilot Trend EPI. Environmental Science \& Policy, 33,171

Janker, J., \& Mann, S. (2020). Understanding the social dimension of sustainability in agriculture: A critical review of sustainability assessment tools. Environment Development and Sustainability, 22, 1671. https://doi.org/10.1007/s10668-018-0282-0.

Johnston, P., Everard, M., Santillo, D., \& Robèrt, K. H. (2007). Reclaiming the definition of sustainability. Environmental Science and Pollution Research, 14, 60.

Kahneman, D., \& Deaton, A. (2014). High income improves evaluation of life but not emotional well-being. Proceedings of National Academy of Sciences, 107, 16489.

Kissinger, M., Sussman, C., Moore, J., \& Rees, W. (2013). Accounting for the ecological footprint of materials in consumer goods at the urban scale. Sustainability, 5, 1960.

Kravchenko, M., Pigosso, D., \& McAloone, T. (2020). A procedure to support systematic selection of leading indicators for sustainability performance measurement of circular economy initiatives. Sustainability, 12, 951. https://doi.org/10.3390/su12030951.

Levrel, H., Kerbiriou, C., Couvet, D., \& Weber, J. (2009). OECD pressure-state-response indicators for managing biodiversity: A realistic perspective for a French biosphere reserve. Biodiversity and Conservation, $18,1719$.

Liu, G., Brown, M. T., \& Casazza, M. (2017). Enhancing the sustainability narrative through a deeper understanding of sustainable development indicators. Sustainability, 9, 1078.

Lucia, U. (2016). Econophysics and bio-chemical engineering thermodynamics: The exergetic analysis of a municipality. Physica A, 462, 421.

Lucia, U., \& Grisolia, G. (2018). Cyanobacteria and Microalgae: Thermoeconomic considerations in biofuel production. Energies, 11, 156.

Lucia, U., \& Grisolia, G. (2017). Unavailability percentage as energy planning and economic choice parameter. Renewable \& Sustainable Energy Reviews, 75, 197.

Lucia, U., \& Grisolia, G. (2018). Cyanobacteria and Microalgae: Thermoeconomic considerations in biofuel production. Energies, 11, 156.

Lucia, U., \& Grisolia, G. (2019). Exergy inefficiency: An indicator for sustainable development analysis. Energy Reports, 5, 62.

Lucia, U., \& Grisolia, G. (2021). Irreversible thermodynamics and Bioeconomy: Towards a human oriented sustainability. Frontiers in Physics, 9, 659342. https://doi.org/10.3389/fphy.2021.659342.

Lucia, U., \& Grisolia, G. (2021). The Gouy-Stodola theorem-from irreversibility to sustainability-the thermodynamic human development index. Sustainability, 13, 3995. https://doi.org/10.3390/su13073995.

Mayer, F. D., Brondani, M., Carrillo, M. V., Hoffmann, R., \& Lora, E. S. (2020). Revisiting energy efficiency, renewability, and sustainability indicators in biofuels life cycle: Analysis and standardization proposal. Journal of Cleaner Production, 252, 119850. https://doi.org/10.1016/j.jclepro.2019.119850.

Meadows, D., Meadows, D., Randers, J., \& Behrens-III, W. (1972). The limits to growth. New York: Potomac Associates - Universe Books.

Mensah, J. (2019). Sustainable development: Meaning, history, principles, pillars, and implications for human action: Literature review. Cogent Social Sciences, 5, 1653531. 
Meramo-Hurtado, S., \& González-Delgado, A. (2020). Aggregate/weighted global sustainability and exergy metric for assessing emerging transformation technologies. ACS Sustainable Chemistry and Engineering, 8, 16637. https://doi.org/10.1021/acssuschemeng.0c06046.

Moldan, B., Janoušková, S., \& Hák, T. (2012). How to understand and measure environmental sustainability: Indicators and targets. Ecological Indicators, 17, 4.

Moran, D., Wackernagel, M., Kitzes, J., Goldfinger, S., \& Boutaud, A. (2008). Measuring sustainable development - nation by nation. Ecological Economics, 64, 470. https://doi.org/10.1016/j.ecolecon.2007.08. 017.

Munda, G. (2005). Measuring sustainability: A multi-criterion framework. Environment Development and Sustainability, 7, 117. https://doi.org/10.1007/s10668-003-4713-0.

Neri, A., Cagno, E., Lepri, M., \& Trianni, A. (2021). A triple bottom line balanced set of key performance indicators to measure the sustainability performance of industrial supply chains. Sustainable Production and Consumption, 26, 648. https://doi.org/10.1016/j.spc.2020.12.018.

Neumayer, E. (1999). The ISEW: Not an index of sustainable economic welfare. Social Indicators Research, 48, 77.

Nourry, M. (2008). Measuring sustainable development: Some empirical evidence for France from eight alternative indicators. Ecological Economics, 67, 441. https://doi.org/10.1016/j.ecolecon.2007.12. 019.

OECD. (1993). OECD core set of indicators for environmental performance reviews. OECD - Organization for Economic Co-operation and Development, Paris: Report.

OECD. (2019). OECD compendium of productivity indicators 2019. Paris: OECD Publishing.

Pascale, A. D., Arbolino, R., Szopik-Depczyńska, K., Limosani, M., \& Ioppolo, G. (2021). A systematic review for measuring circular economy: The 61 indicators. Journal of Cleaner Production, 281, 124942. https://doi.org/10.1016/j.jclepro.2020.124942.

Pinar, M., Stengos, T., \& Topaloglou, N. (2017). Testing for the implicit weights of the dimensions of the human development index using stochastic dominance. Economics Letters, 161, 38.

Primc, K., Kalar, B., Slabe-Erker, R., Dominko, M., \& Ogorevc, M. (2020). Circular economy configuration indicators in organizational life cycle theory. Ecological Indicators, 116, 106532. https://doi. org/10.1016/j.ecolind.2020.106532.

Primc, K., Kalar, B., Slabe-Erker, R., Dominko, M., \& Ogorevc, M. (2020). Circular economy configuration indicators in organizational life cycle theory. Ecological Indicators, 116, 106532. https://doi. org/10.1016/j.ecolind.2020.106532.

Purvis, B., Mao, Y., \& Robinson, D. (2019). Three pillars of sustainability: In search of conceptual origins. Sustainability Science, 14, 681.

Raucci, D., \& Tarquinio, L. (2020). Sustainability performance indicators and non-financial information reporting. Evidence from the Italian Case, Administrative Sciences, 10, 13. https://doi.org/10.3390/ admsci10010013.

Rees, W. E. (1992). Ecological footprints and appropriated carrying capacity: What urban economics leaves out. Environment and Urbanization, 4, 121.

Romero, J., \& Linares, P. (2014). Exergy as a global energy sustainability indicator. A review of the state of the art, Renewable and Sustainable Energy Reviews, 33, 427. https://doi.org/10.1016/j.rser.2014. 02.012 .

Rossi, E., Bertassini, A., dos Santos Ferreira, C., Neves do Amaral, W., \& Ometto, A. (2020). Circular economy indicators for organizations considering sustainability and business models: Plastic, textile and electro-electronic cases. Journal of Cleaner Production, 247, 119137. https://doi.org/10. 1016/j.jclepro.2019.119137.

Sagar, A. D., \& Najam, A. (1998). The human development index: A critical review. Ecological Economics, 25, 249.

Santagata, R., Zucaro, A., Viglia, S., Ripa, M., Tian, X., \& Ulgiati, S. (2020). Assessing the sustainability of urban eco-systems through Emergy-based circular economy indicators. Ecological Indicators, 109, 105859. https://doi.org/10.1016/j.ecolind.2019.105859.

Schaefer, A., \& Crane, A. (2005). Addressing sustainability and consumption. Journal of Macromarketing, 25, 76.

Sciubba, E. (2013). Can an environmental indicator valid both at the local and global scales be derived on a thermodynamic basis? Ecological Indicators, 29, 125. https://doi.org/10.1016/j.ecolind.2012.12.008.

Sciubba, E. (2019). Exergy-based ecological indicators: From Thermo-Economics to cumulative exergy consumption to Thermo-Ecological Cost and Extended Exergy Accounting. Energy, 169, 462. https://doi.org/10.1016/j.energy.2018.11.101.

Sciubba, E., \& Zullo, F. (2011). Is sustainability a thermodynamic concept? International Journal of Exergy, 8, 68. 
Shi, X., Matsui, T., Machimura, T., Gan, X., \& Hu, A. (2020). Toward sustainable development: Decoupling the high ecological footprint from human society development: A case study of Hong Kong. Sustainability, 12, 4177.

Siche, J., Agostinho, F., Ortega, E., \& Romeiro, A. (2008). Sustainability of nations by indices: Comparative study between environmental sustainability index, ecological footprint and the emergy performance indices. Ecological Economics, 66, 628. https://doi.org/10.1016/j.ecolecon.2007.10.023.

Spangenberg, J., Pfahl, S., \& Deller, K. (2002). Towards indicators for institutional sustainability: Lessons from an analysis of Agenda 21. Ecological Indicators, 2, 61.

Steuer, R. (2013). Objectives and indicators in sustainable development strategies: Similarities and variances across Europe. Sustainable Development, 21, 224. https://doi.org/10.1002/sd.501.

Strezov, V., Evans, A., \& Evans, T. (2016). Assessment of the economic, social and environmental dimensions of the indicators for sustainable development. Sustainable Development, 25, 242. https://doi.org/ 10.1002/sd.1649.

Tausch, A. A. (2011). Costa Rica, Superstar? some reflections on the global drivers and bottlenecks of the happy planet index. SSRN, 8, 1. https://doi.org/10.2139/ssrn.1924130.

Türe, C., \& Türe, Y. (2021). A model for the sustainability assessment based on the human development index in districts of Megacity Istanbul (Turkey). Environment Development and Sustainability, 23, 3623. https://doi.org/10.1007/s10668-020-00735-9.

UNDESA, CSD (1996). Indicators of sustainable development. Report, United Nations, New York: Framework and Methodologies.

UNDESA, CSD (1996). Indicators of sustainable development, framework and methodologies. Report. New York: United Nations

UNDP Human Development Report Office. (2015). Training material for producing national human development reports. UNDP, New York: Occasional paper.

United Nations. (2015). Transforming our World: The 2030 Agenda for Sustainable Development. United Nations: Report.

United Nations Development Programme. (1990). Human development report 1990: Concept and measurement of human development. UNDP, New York: Tech. rep.

United Nations General Assembly (1992). Report of the united nations conference on environment and development - Agenda 21. Report, United Nations

Wackernagel, M., \& Rees, W. (1997). Our ecological footprint. Basel: Birkhouse Publishing.

Wilson, J., Tyedmers, P., \& Pelot, R. (2007). Ecological Indicators, 7, 299.

WCED. (1987). Our common future. Oxford: Oxford University Press.

Zhang, T. W., \& Dornfeld, D. A. (2007). In: Advances. In S. Takata \& Y. Umeda (Eds.), Life cycle engineering for sustainable manufacturing businesses (pp. 189-193). London: Springer-Verlag.

Publisher's Note Springer Nature remains neutral with regard to jurisdictional claims in published maps and institutional affiliations. 